\title{
New Competencies-Based Curriculum of Computing in General Basic Education Schools in Latvia and its Testing
}

\author{
Viesturs VEZIS, Ojars KRUMINS \\ Faculty of Computing, University of Latvia, Raina bulv. 19, LV-1586, Riga, Latvia \\ viesturs.vezis@lu.lv, zm33068@lu.lv
}

\begin{abstract}
Annotation. As the economy in Latvia and the world develops, there is an increasing need for computer specialists, including in the information technology sector. That means that training of specialists for professional orientation must begin among schoolchildren in the lowest grades. The authors of this paper were involved in developing new computing education content in general basic education schools, also leading working groups to discuss computing studies from the $1^{\text {st }}$ to the $9^{\text {th }}$ grade (7-16 years old) and offering full methodological support for each class. The new computing content was supervised carefully as it was successfully tested in 150 pilot schools between 2015 and 2018. It will be introduced at all schools as of September 1, 2020.
\end{abstract}

Keywords: didactics of computing, informatics, computing, education, ICT.

\section{The Context of the Need for a New Computing Studies Curriculum in 2014/2015}

According to Eurostat data from 2015, one in five companies hire information and communications technology (ICT) specialists. Approximately $35 \%$ of companies reported that it was hard to find such specialists in 2014 (Eurostat, 2015). Only 2.2\% of the residents of Latvia are employed in ICT areas, while the European average is $3.5 \%$. That means that we face the great challenge of increasing the number of trained ICT specialists, offering them a chance to find jobs in Latvia and in the European Union (Eurostat, 2019a). It must be noted that there was gender segregation in the ICT sector in 2014, with only $23 \%$ of the sector's employees being women (Eurostat, 2019b). Forecasts from the European Commission say that by 2020 , there will be 825,000 vacancies in the ICT sector (European Commission, 2016). It is also true that representatives of an increasing number of professions require digital skills (it is predicted that up to $90 \%$ of employers will require such skills in the near future). The Latvian National Development Plan for 2014-2020 very much emphasises highly productive and export-capable manufacturing, internationally competitive services, and highly developed research and innovations. This will not be possible without the development of computer skills (PKC, 2012).

For more than ten years now, all schools in Latvia have taught basic computer skills to students in the $5^{\text {th }}, 6^{\text {th }}, 7^{\text {th }}, 10^{\text {th }}$ and $11^{\text {th }}$ grade (Vezis and Krumins, 2018), but only a 
few schools teach the knowledge and skills that are needed to create new ICT products algorithmic thinking, as well as coding skills. According to statistics from the Ministry of Education and Science about the 2014/15 school year, only 37 of 354 high schools in Latvia were offering classes that include basic coding skills - 15 in Riga, five in Valmiera, two in Daugavpils and two in Liepaja. This situation does not satisfy ICT employers or universities that offer courses in computing studies.

According to studies organised by the European Schoolnet in 2014 (Balanskat and Engelhardt, 2014) and 2015 (Balanskat and Engelhardt, 2015), research data about computing studies in 22 European countries (Austria, Belgium, Bulgaria, Cyprus, the Czech Republic, Denmark, Estonia, Finland, France, Greece, Hungary, Ireland, Lithuania, Luxembourg, Malta, the Netherlands, Norway, Poland, Portugal, Slovakia, Spain and the United Kingdom) can, to a certain extent, be divided up into six areas of topics, and this data shows these groups and the number of countries in which they are taught:

- Digital competence - 17

- $\quad$ ICT user skills - 18

- $\quad$ ICT as a tool for learning - 18

- Fostering logical thinking - 16

- $\quad$ Fostering coding skills - 13

- Fostering problem solving - 15

This study shows that a comparison of data in 2014 and 2015 and the distinct near-term prognoses of countries mean that each year there is an increase in the number of countries which include elements of logical thinking and coding in the educational programmes of their schools. Several countries are actively involved in initiatives aimed at ensuring computing content at various levels, including primary schools, general basic education schools and high schools. This goal is not related to training professionals, instead introducing schoolchildren to the subject and the relevant research so as to enhance interest in this topic (Armoni and Gal-Ezer, 2014). Much emphasis is on computational thinking (Wing, 2006). Computing studies at schools in the past were mostly restricted to high schools, but some countries such as Greece started to teach computing to children from the age of six (Jones, 2011). At this time, there is an active introduction of computing studies at primary schools in several countries. In the United Kingdom, for instance, there have been active discussions about this since 2012, and organisations such as the "Computing at School Working Group" and "BCS, The Chartered Institute for IT" were asked to prepare standards for computing classes (Jones et al., 2013). The result was that beginning in 2014 (Berry, 2013), the UK had a new and mandatory computing standard for students of all ages (Department for Education, 2013).

The time has come for immediate changes in the educational content of schools in Latvia, ensuring earlier studies of computing issues and changing the content to include algorithmic and logical thinking and coding foundations for all schoolchildren. This will ensure that young people in Latvia are competitive at the European and world level, not least in terms of the labour market. It would also facilitate the development of Latvia's ICT sector.

\section{Development of new computing content}

At the time when this paper was written, the general basic education standard (MK, 2014) had not been changed since 2004 when it comes to computing, that means that it is far behind rapid trends in the development of the relevant sector and is only focused on 
ICT-related knowledge and skills, not the knowledge and skills that are needed for new participants in the ICT system. Before offering their concepts to schools, these authors studied a 2013 study that was conducted by the world's largest computing education and science association, the Association for Computing Machinery. The study offered recommendations (Gander et al., 2013), among which we will emphasise three in relation to new computing content:

- Digital literacy must be taught to everyone up to the age of 12, including not just basic skills, but also aspects of effectiveness, ethics and security;

- All students must study computing as a separate area of science, also using it in other areas of study;

- There must be an extensive teacher training programme that would involve the academic environment, as well as representatives of the relevant industries.

A good catalyst and amount of support for the authors' initiative about changes to school curricula in the area of computing studies came not just from businesspeople, but also from informatics teachers. A conference of the Latvian Association of Informatics Teachers in 2014 adopted a resolution (Gaile, 2014, Derkevica-Pilskunga, 2014) about the need to revisit curriculum issues in the area of computing studies at schools, as well as to start teaching the relevant subjects to students at a younger age. The resolution was submitted to the Ministry of Education and Science, and the ministry's state secretary expressed her support by setting up a working group late in 2014 to draft a new curriculum in computing for general basic education schools (Kuzmina, 2015). The working group included informatics teachers, faculty members from universities, representatives from professional associations in the sector, as well as representatives from the ministry and the National Centre for Education. The chairman of the group was Viesturs Vēzis (VISC, 2015a). Over the course of three months, the group developed five sample computing study programmes at the general basic education school level:

- A sample programme for the $1^{\text {st }}$ to the $9^{\text {th }}$ grade at schools which teach maths, natural sciences and technical subjects (Vezis et al., 2015a);

- A sample programme with a series of questions for the integrated teaching of these subjects from the $1^{\text {st }}$ to the $3^{\text {rd }}$ grade (Vezis et al., 2015b);

- A sample programme for the $4^{\text {th }}$ to the $6^{\text {th }}$ grade (Vezis et al., 2015c);

- A sample programme for the $7^{\text {th }}$ to the $9^{\text {th }}$ grade (Vezis et al., 2015d);

- A sample programme for more in-depth studies of the topics from the $7^{\text {th }}$ to the $9^{\text {th }}$ grade, focusing on students who have greater interest in coding and algorithms (Vezis et al., 2015e).

The working group took into account the rapid development of the computing sector and proposed that the new programmes be introduced in the $1^{\text {st }}, 4^{\text {th }}$ and $7^{\text {th }}$ grade, also suggesting that the content of the curriculum be reviewed once every three years and that the studies also begin at the $10^{\text {th }}$ grade (Figure 1).

In implementing this model, it must be taken into account that students who entered the $4^{\text {th }}$ grade in 2015,2016 and 2017 will not have taken the relevant classes from the $1^{\text {st }}$ to the $3^{\text {rd }}$ grade, while students entering the $7^{\text {th }}$ grade had studied informatics only in the $5^{\text {th }}$ and $6^{\text {th }}$ grade in line with a sample programme for this subject (Vezis et al., 2006). These factors were taken into account when preparing sample programmes for the $4^{\text {th }}$ to the $6^{\text {th }}$ and then again for the $7^{\text {th }}$ to the $9^{\text {th }}$ grade. This approach is essential, because students who entered the $1^{\text {st }}$ grade in 2015 will only finish high school in 2027 (Figure 1) and university no earlier than in 2030. The proposed approach, in turn, means that the first results will already be obtained in mid-2021. 


\begin{tabular}{|c|c|c|c|c|c|c|c|c|c|c|c|c|c|c|c|c|c|c|c|c|c|c|c|c|}
\hline Year & Gra & des & & & & & & & & & & & & & & & & & & & & & & \\
\hline 2015 & 7 & 6 & 5 & 4 & 3 & 2 & 1 & & & & & & & & & & & & & & & & & \\
\hline 2016 & 8 & 7 & 6 & 5 & 4 & 3 & 2 & 1 & & & & & & & & & & & & & & & & \\
\hline 2017 & 9 & 8 & 7 & 6 & 5 & 4 & 3 & 2 & 1 & & & & & & & & & & & & & & & \\
\hline 2018 & 10 & 9 & 8 & 7 & 6 & 5 & 4 & 3 & 2 & 1 & & & & & & & & & & & & & & \\
\hline 2019 & 11 & 10 & 9 & 8 & 7 & 6 & 5 & 4 & 3 & 2 & 1 & & & & & & & & & & & & & \\
\hline 2020 & 12 & 11 & 10 & 9 & 8 & 7 & 6 & 5 & 4 & 3 & 2 & 1 & & & & & & & & & & & & \\
\hline 2021 & & 12 & 11 & 10 & 9 & 8 & 7 & 6 & 5 & 4 & 3 & 2 & 1 & & & & & & & & & & & \\
\hline 2022 & & & 12 & 11 & 10 & 9 & 8 & 7 & 6 & 5 & 4 & 3 & 2 & 1 & & & & & & & & & & \\
\hline 2023 & & & & 12 & 11 & 10 & 9 & 8 & 7 & 6 & 5 & 4 & 3 & 2 & 1 & & & & & & & & & \\
\hline 2024 & & & & & 12 & 11 & 10 & 9 & 8 & 7 & 6 & 5 & 4 & 3 & 2 & 1 & & & & & & & & \\
\hline 2025 & & & & & & 12 & 11 & 10 & 9 & 8 & 7 & 6 & 5 & 4 & 3 & 2 & 1 & & & & & & & \\
\hline 2026 & & & & & & & 12 & 11 & 10 & 9 & 8 & 7 & 6 & 5 & 4 & 3 & 2 & 1 & & & & & & \\
\hline 2027 & & & & & & & & 12 & 11 & 10 & 9 & 8 & 7 & 6 & 5 & 4 & 3 & 2 & 1 & & & & & \\
\hline 2028 & & & & & & & & & 12 & 11 & 10 & 9 & 8 & 7 & 6 & 5 & 4 & 3 & 2 & 1 & & & & \\
\hline 2029 & & & & & & & & & & 12 & 11 & 10 & 9 & 8 & 7 & 6 & 5 & 4 & 3 & 2 & 1 & & & \\
\hline 2030 & & & & & & & & & & & 12 & 11 & 10 & 9 & 8 & 7 & 6 & 5 & 4 & 3 & 2 & 1 & & \\
\hline 2031 & & & & & & & & & & & & 12 & 11 & 10 & 9 & 8 & 7 & 6 & 5 & 4 & 3 & 2 & 1 & \\
\hline 2032 & & & & & & & & & & & & & 12 & 11 & 10 & 9 & 8 & 7 & 6 & 5 & 4 & 3 & 2 & 1 \\
\hline
\end{tabular}

Figure 1. A schedule for the introduction of the new computing curriculum at various grade levels.

In preparing its offer for the curriculum, the working group thought about the needs of the people of Latvia, the labour market and the educational system, also taking into account 2013 recommendations from Association for Computing Machinery Europe (Joint Task Force on Computing Curricula, Association for Computing Machinery (ACM) and IEEE Computer Society, 2013) in terms of digital literacy and basic skills":

- Knowing how to work with documents, presentations and graphics;

- Knowing how to work with databases;

- Knowing how to search for and save information;

- Knowing how to use E-mail, social networks and forums;

- Knowing how to select tools that are appropriate for each process.

There is also a focus on ethics and security:

- Knowing how to behave ethically on the Internet;

- Knowing how to differentiate between reality and the virtual environment;

- Understanding problems related to security and fraud;

- Knowing how to evaluate information from the Internet in a critical way;

- Knowing how to use information properly and understanding plagiarism;

- Knowing about privacy issues, the protection of data and respect for the privacy of others.

The recommendations also emphasise the fact that the computing sector is calling for a change in the thinking of students, including an offer of new ways to deal with problems:

- Representing information abstractly (models, simulations);

- Data structuring and analysis; 
- Automatization of solutions by using algorithmic thinking and other methods. Also changing intellectual habits:

- Experience in working with complex system;

- Persistence when dealing with difficult problems;

- Tolerance toward a lack of specificity (is the system working as it is supposed to?);

- Taking into account both human and technical aspects (user needs, interfaces, etc.);

- Being able to communicate and work with others in pursuit of the goal.

This is the basic goal of all of the sample programmes that were prepared by the working group: "Facilitating the improvement and practical development of skills (competences) in the area of computing, doing so in accordance with developmental trends in the computing sector and so as to ensure that diverse life situation information can be obtained, processed, analysed and shaped, also ensuring effective use of information and communications technologies in the teaching process." This will involve the following elements:

- Learning about the fundamental concepts of computing;

- Learning and developing digital, information and media literacy;

- Gaining experience with programmable devices and systems;

- Developing persistence when dealing with educational and everyday issues;

- Developing logical and algorithmic thinking;

- Being able to structure and analyse data so as to identify and resolve problems individually or in a group;

- Getting into the habit of working with programmable devices in a safe environment (both physical and virtual), also learning about ways of avoiding or reducing the likelihood of possible threats;

- Understanding the rapid development of the computing sector and its influence on the economy and society;

- Being motivated to develop skills to become a fully-fledged member of the information society.

The content of education in the programmes is divided up into four components:

- The fundamentals of computing and programmable devices;

- Applications;

- Algorithms and coding;

- Technical, ethical and legal aspects of computer use to ensure one's own safety and that of others.

When work began on the curricula, the working group evaluated global experience in selecting topics for computing classes and the systematic approach so that Latvia's labour market requirements could be satisfied. The group also thought about the specifics of Latvia's educational system. The following aspects were particularly considered:

- Whether the curricula would be focused only on the consumer society or we would establish new indicators related to equipment, technologies and services;

- Whether ICT use in the educational process would be a goal unto itself or a resource for purposeful and sensible educational processes;

- How to adapt "ideal" curricula to the technical and intellectual capacities of schools;

- How to adapt schools and university educational content in the area of computing; 
- How to make sure that the curricula focus on the various needs of everyone in society and the labour market so as to satisfy the needs of people who use ICT only for personal needs, those who use ICT as a tool in their profession, and those who will be professionals in the field of computing.

After considering all of these aspects, the working group decided that there would be conceptual proportions in terms of the curricula in groups of grades:

- $1^{\text {st }}$ to $3^{\text {rd }}$ grade:

$\circ \quad$ ICT use and security $(80 \%)$;

- $4^{\text {th }}$ to $6^{\text {th }}$ grade:

- Development of algorithmic thinking (20\%).

$\circ \quad$ ICT use and security $(67 \%)$;

$\circ$ Development of algorithmic thinking and basic coding skills (33\%).

- $7^{\text {th }}$ to $9^{\text {th }}$ grade:

- ICT use and security (50\%), including the ability of students to earn the internationally recognised European Computer Driver's Licence;

- Development of algorithmic thinking and basic coding skills (50\%);

- An opportunity to learn coding to a greater degree.

- At the high school level, students would be given an opportunity to specialise in a particular area. That means that after completing general basic education school, where the proposed sample curricula were used, students would be ready to enter the job market or continue their studies at the next level, because the knowledge and skills would allow them to earn the European Computer Driver's Licence and learn about the computing sector and the relevant professions for career development purposes.

\section{Methodological support for the new curricula in computing}

After selecting the content and drafting the sample curricula, these authors received financial support from businesses in the ICT sector to establish a working group with 14 experienced informatics teachers and researchers so as to ensure full methodological support for each lesson, as well as to ensure the first implementation of the new curricula, testing them fully during a three-year educational period from 2015 to 2018. The methodological elements were prepared for 524 lessons ( 6,000 pages), as divided up among grade levels in the following way:

- $\quad 1^{\text {st }}$ grade -34

- $\quad 2^{\text {nd }}$ grade -35

- $3^{\text {rd }}$ grade -35

- $4^{\text {th }}$ grade -35

- $5^{\text {th }}$ grade -35

- $6^{\text {th }}$ grade -35

- $7^{\text {th }}$ grade -35

- $7^{\text {th }}$ grade (in depth) -70

- $8^{\text {th }}$ grade -35

- $8^{\text {th }}$ grade (in depth) -70

- $9^{\text {th }}$ grade -35

- $9^{\text {th }}$ grade (in depth) -70

The materials are available to all students, teachers and others at http://datorika.startit. IV. The materials are free and are available with free registration or authorisation from account of a school management system. Methodological support for each lesson contains the following elements:

- The topic of the lesson

- The goals of the lesson

- The tasks of the lesson 
- The results that are to be achieved

- Organisational forms and learning methods

- Forms and methods to evaluate the achievements of students

- Cross curricular links

- Transversal topics

- Opportunities to deepen the topic for more capable students

- Recommended exercises

- Recommended individual work

- Approximate plans for the lesson

- The necessary resources

- The sources (books, web pages, etc.) of education that can be used.

This methodological support is available from two perspectives - one for the teacher (Figure 2), the other for students (Figure 3).

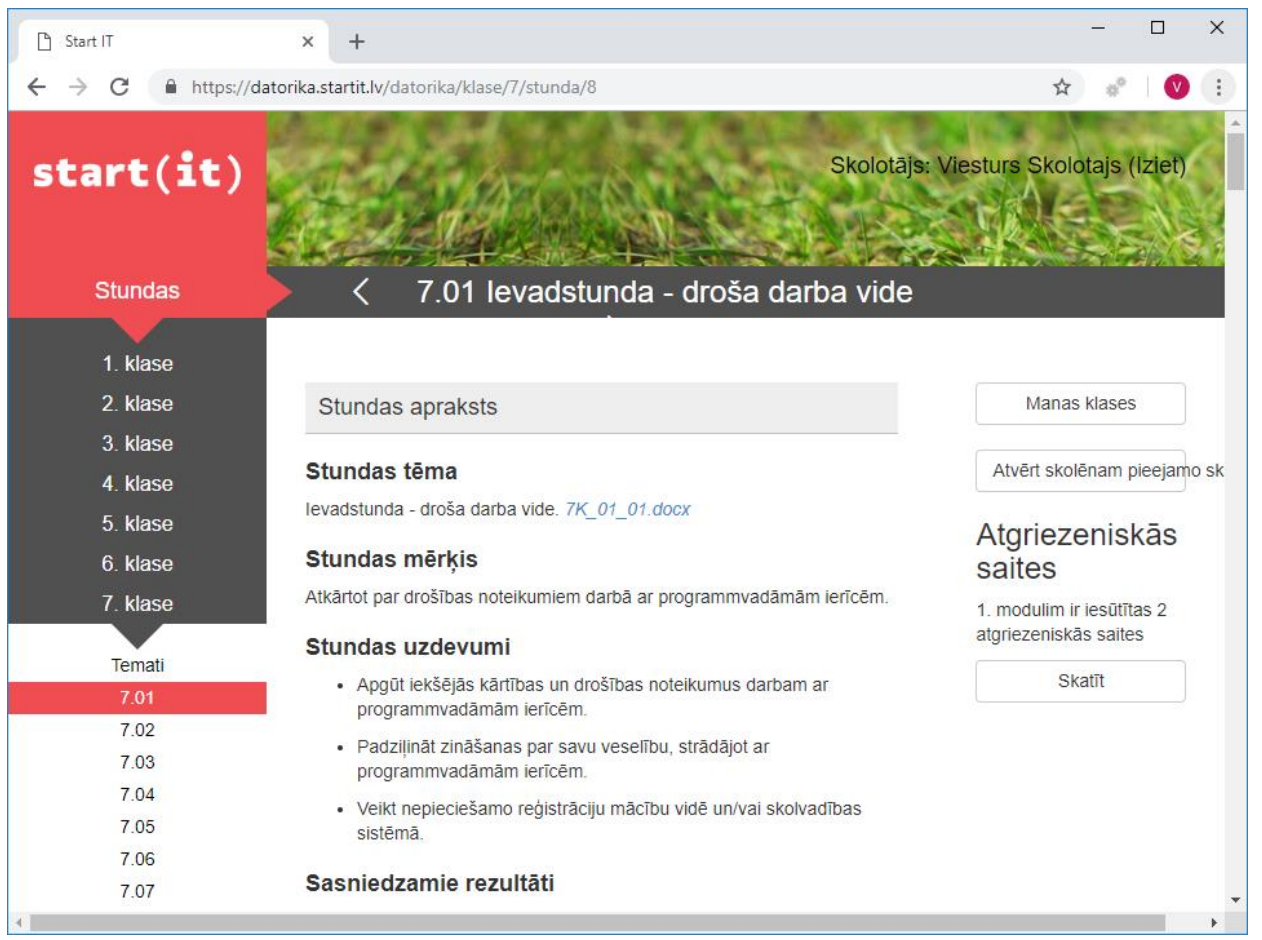

Figure 2. A fragment from the methodological support materials that are available to teachers for each lesson (datorika.startit.lv) 


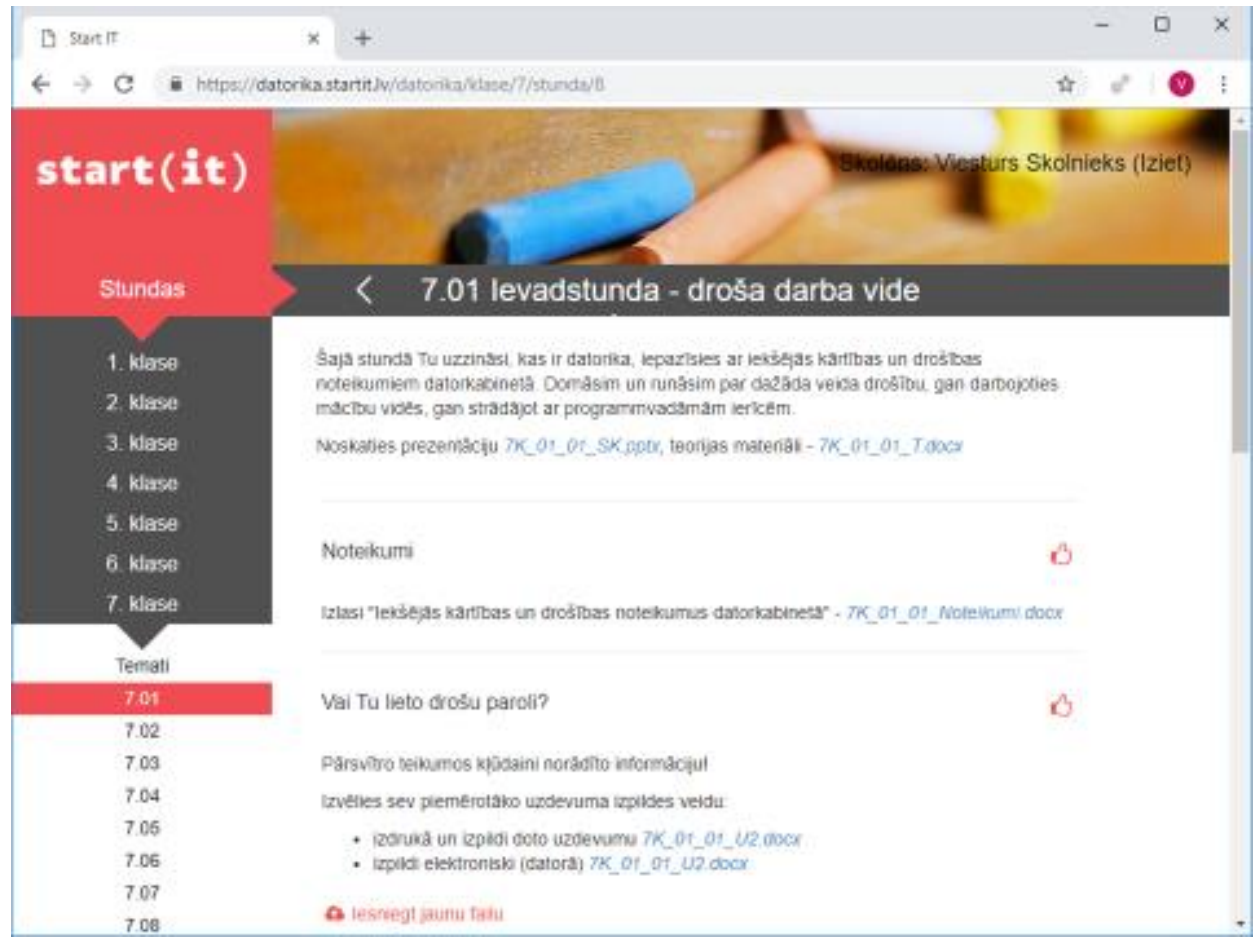

Figure 3. A fragment from the methodological materials that are available to students for each lesson (datorika.startit.lv)

Teachers have access to lesson plans with all necessary support and materials to be distributed to students. They can also tack and evaluate the work that students do. Each material asks four questions so as to ensure a quick reciprocal look at each lesson:

- How targeted and result-focused is the teaching process during the lesson?

- How were you able to implement all of the lesson plans?

- Did the provided teaching methods motivate students to do the work?

- Did the teaching methods, work organisation forms and relevant materials lead to the desired results in the lesson?

There is also space for free-form comments, questions and proposals as to how lessons can be improved. The portal also helps teachers to attach students and to manage their activities on the portal.

Students, in turn, have access to all of the educational and support materials for the lesson, as well as exercises texts and tests that can be completed electronically and then sent to the teacher. There is also a special environment for exercises and tasks related to basic coding and Webpage design skills. 


\section{Testing and evaluating the curricula for general basic education in computing}

Testing of the general basic education curricula for computing was done in close partnership with the National Centre for Education. On May 15, 2015, the centre offered 157 pilot schools (VISC, 2015b), and on September 1 of the same year, testing began at 154 of them (IZM, 2015), thus representing 19\% of all schools in Latvia (IZM, 2019). Each school could volunteer to take part in the experiment, but these pilot schools fully represented the full spectrum of schools in Latvia:

- Size (small ones with up to 15 students in each grade, as well as medium schools and large schools with three or more parallel classes at each grade level and some 30 students in each class);

- Type of schools (primary, general basic education and high schools);

- Location (villages, cities, administrative district centres, large cities);

- Schools for students with special needs and schools, which include such students.

The testing lasted for three years to evaluate each phase in education (grades 1-3, 4-6 and 7-9). After the three years, 141 pilot schools (12 primary schools, 34 general basic education schools and 94 high schools) had completed the testing. This represented $19 \%$ of all schools (IZM, 2019), but at least 100 other schools indicated interest in the curricula and offered them to their students. The reduction in the number of pilot schools was largely down to optimisation of Latvia's school network (IZM, 2018), which led to the relevant school being reorganised or merged with another one. Two pilot schools withdrew from the process because they did not have appropriate teachers. The new curriculum for computing was used for one lesson (40 minutes) per week. In order not to violate laws about the of lessons for students per week, it was hard to find that additional hour in the $8^{\text {th }}$ and $9^{\text {th }}$ grade, as well as to find two hours for more in-depth studies. The result was that the following number of schools completed the full three-year testing of the sample curricula and methodological support:

- $\quad 1^{\text {st }}$ to $3^{\text {rd }}$ grade -103 pilot schools;

- $\quad 4^{\text {th }}$ to $6^{\text {th }}$ grade -97 pilot schools;

- $7^{\text {th }}$ to $9^{\text {th }}$ grade -54 pilot schools

- $7^{\text {th }}$ to $9^{\text {th }}$ grade in depth -9 pilot schools.

At the end of the three-year test period, all schools and teachers who were involved in the process were surveyed. The first questionnaire focused on:

- Which classes and how many students were involved in the testing process;

- How many teachers and with what level of professional readiness were involved in the testing;

- How often teachers used the offered methodological support and the Start(IT) portal;

- Whether the methodological support was sufficient, or whether there was a need for additional materials and improvements;

- The time spent on preparing for each lesson;

- Whether and what kind of knowledge and skills developed by students in computing were of use in other educational subjects and in everyday life. 
The second questionnaire asked for detailed information about how the classes were organised, how students did in the classes, how prepared were the students in advance, growth and achievements in each area, etc.:

- Was there content that students were already familiar with?

- Was the content appropriate for the age level, and if not, why not?

- Were the planned results achieved?

- Were the tasks related to real life?

- Were students motivated to learn the subject?

- Did the lesson plan and methodological support conform to the planned results?

- What difficulties did students and the teacher encounter?

- Will the curriculum continue to be offered in the same way, and if not, what will be changed?

The questionnaires about the evalutation at the pilot schools were received as follows:

- Questionnaires in 2016 from 236 teachers who taught the classes to 9084 students;

- Questionnaires in 2017 from 227 teachers who taught the classes to 8568 students;

- Questionnaires in 2018 from 232 teachers who taught the classes to 8020 students.

In parallel to these questionnaires, the working group also observed 25 lessons at various types of schools.

\section{Results of the testing}

For the first time, Latvia has curricula and methodological support for each computing lesson from the 1st to the 9th grade. Such support is not offered in any other subject area in Latvia in terms of scope and level of detail. User statistics from the Start(IT) portal, where the materials were available, showed that as of May 31, 2018, the portal had been used by 771 teachers from 442 schools (Figure 4) and more than 25,000 registered students (Figure 5).

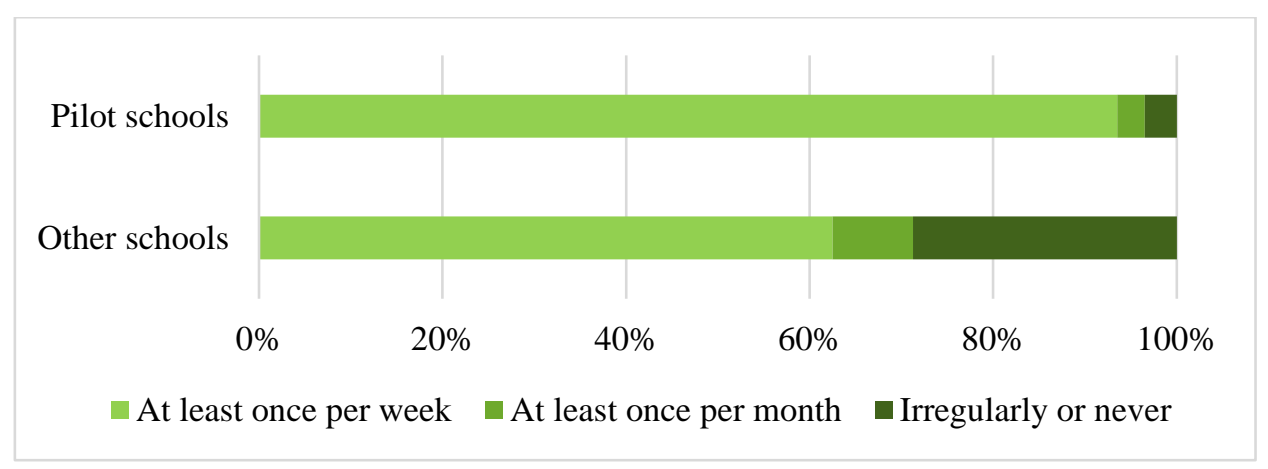

Figure 4. Teachers accessing the methodological support on the portal 


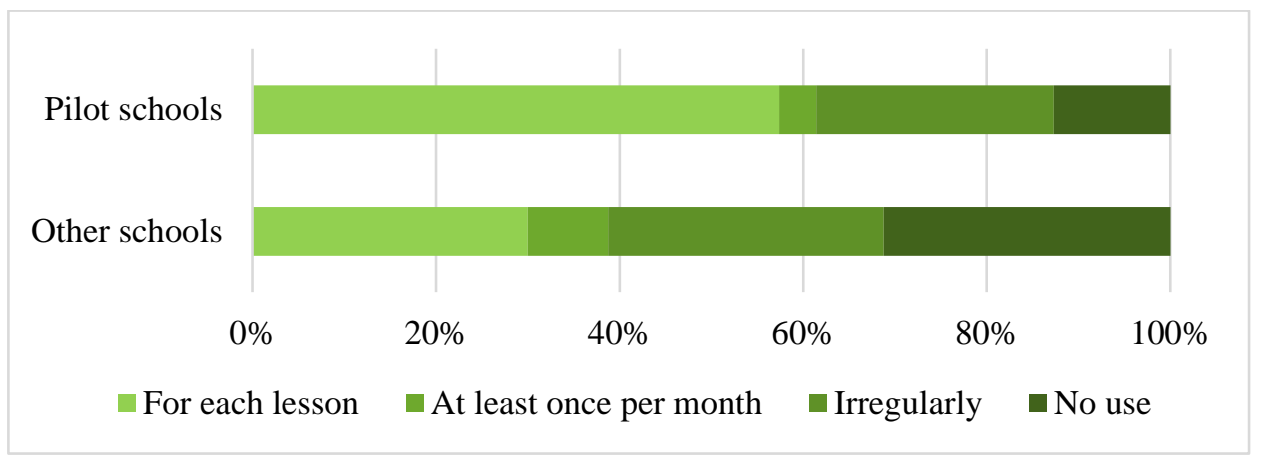

Figure 5. Students accessing the methodological support on the portal

For the purposes of this paper, we will only focus on the most important results from the teacher questionnaire:

- $95 \%$ of surveyed teachers praised the methodological support. Several teachers wrote that they would like to have more than one sample of tests. Also they would like to have more exercise and independent work assignments so as to diversify the process and make it appropriate for students with various levels of readiness;

- Despite the fact that there was a detailed plan for each lessons, teachers said that on average, they needed 38 minutes (ranging from 10 minutes to two hours) to prepare for a 40 -minute lesson;

- $46 \%$ of respondents said that the knowledge and skills from computing classes were very useful in studying other subjects and for everyday purposes, $38 \%$ said that they were useful, $15 \%$ had a neutral answer to the questions, and only $1 \%$ said that the knowledge and skills were not useful;

- $29 \%$ of respondents said that computing studies very much facilitate the development of algorithmic and logical thinking that is necessary in other subject areas, $46 \%$ said that they develop it, $23 \%$ had a neutral attitude, and $2 \%$ said that they do not develop it;

- Because students can gain knowledge and skills at various interest groups or on their own, they arrive at school with various levels of readiness, but the questionnaires indicated several trends; some students felt that they already knew everything that the teacher was discussing even though their knowledge was actually very superficial or even false; more than one-half of students had no knowledge about the curriculum, though many questionnaires noted that there were some students who really were familiar with the topic;

- $94 \%$ of respondents said that the curricula and methodological support were in line with the age group that was the target audience (91\% in relation to the $1^{\text {st }}$ grade up to $97 \%$ in relation to the $9^{\text {th }}$ grade);

- $56 \%$ of respondents said that the curricula and methodological support fully conformed to the planned results, 33\% said that it almost conformed, 9\% said that it partly conformed, and $2 \%$ said that they did not conform at all to the planned results;

- $99 \%$ of respondents said that the elements of each class were linked to real life; 
- $\quad 39 \%$ of teachers said that students had a high level of motivation in learning the content, with $37 \%$ describing it as optimal, $22 \%$ as average, and $2 \%$ as a low level of motivation;

- $34 \%$ of respondents said that they achieved all of the results of the programme, $45 \%$ said that they almost did so, $19 \%$ admitted that the results were achieved only partly, and $2 \%$ said that they were not achieved at all.

When it came to the curriculum planning and implementation and the planned results in each subject area, improvements in the skills and knowledge and students improved in the following six areas, and that was true in each group of classes:

- Correct use of terminology;

- Search for and use of different sources of information and evaluating their validity;

- Sensible use of applications and programmable devices;

- Safe and responsible use of information, data, software and programmable devices;

- Development of logical and algorithmic thinking;

- Developing of new software (programming).

Measurements of student growth were made in each group of classes on a four-point scale - ( 0 meaning no improvements and 3 referring to distinct improvements). In this paper we offer the average indicator for each of the aforementioned areas (Figure 6).

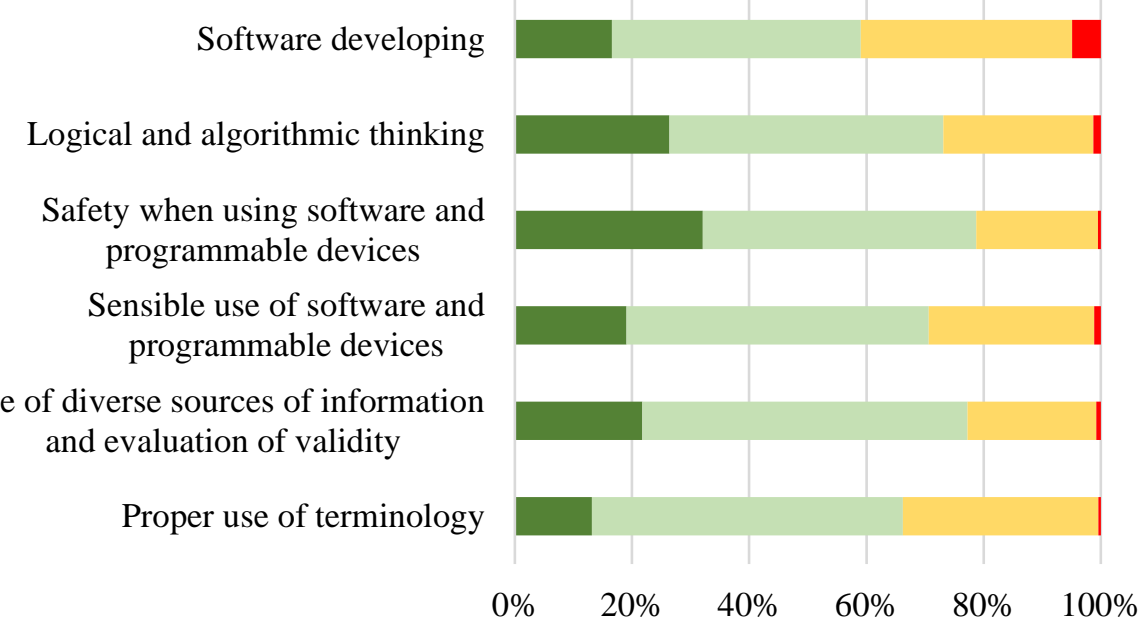

Distinct improvements $\square$ Sufficient improvements

Low improvements $\quad$ No improvements

Figure 6. Improvement of student knowledge and skills in computing studies

It has to be noted that some two-thirds of teachers reported in their questionnaires that computing classes very much improved the knowledge and skills of students in all six areas, particularly in terms of logical and algorithmic thinking. The lowest level of improvements was seen in the developing of new software. 


\section{Discussion}

The authors of this paper would like to point out that during the testing of the computing curricula, enormous work was done to prepare sample lessons and to offer full methodological support on the basis of Latvian and global labour market needs, also keeping in mind the specifics of Latvia's education system. Reams of data were obtained to evaluate proposed solutions, but it must be noted that the authors did not have the necessary resources to conduct measurements of the schoolchildren who were learning the new content. That is why the analysis is only based on data from the questionnaires which teachers filled out. From their perspective, this offers a full understanding of the appropriateness of the new content and the extent to which it is compatible for students of the relevant age group. The data show that the prepared content for computing studies at the general basic education school level is optimal and appropriate for the age group, but there are still three issues that need to be considered.

1. Why did students demonstrate lower growth and learning levels when it came to software development than was the case with other subjects even though the highest indicators related to the development of logical and algorithmic thinking? After looking at the qualification of teachers who were involved in the testing process, the authors concluded that more than $85 \%$ of them had no experience in teaching coding at the relevant educational level. That meant that they were doing so for the first time. This was seen in the fact that $89 \%$ of teachers said that it was much easier for them to teach classes after doing so for one or two years, with teachers feeling more convinced about what they were doing. Similar results (Heintz et al., 2017, Heintz and Mannila, 2018) were obtained by researchers who were studying the introduction of new computing study content in Sweden.

2. At which grade level should computing first be taught? At the primary school level, should it be a separate subject, or should it be integrated into other subject areas? Survey data show that computing studies can begin in the $1^{\text {st }}$ grade ( 7 years old) and that they are appropriate for the age group. During the first year of evalutation, $90 \%$ of schools chose to teach it as a separate topic, with only $10 \%$ integrating it into other subject areas. During the second and third year of testing, however, the number of schools with such integration shrank. Schools said that this was ineffective because it was not possible to access computers during any period of the day. Furthermore, not all teachers were prepared to teach topics related to computing in an adequate way. Other studies (Heintz et al., 2016) have also shown that computing studies become part of the educational process from an early point in schooling, whether that is done in an integrated way (Sweden, Estonia, Finland) or taught as a separate topic (UK, Poland, Norway, USA). After evaluating our data and those of other studies (Heintz and Mannila, 2018, Fernández Cruz et al., 2018), we have concluded that computing as an integrated subject area is risky.

3. Does the content of computing studies facilitate learning in other areas of education? The survey data and results from other researchers (Kalelioğlu, 2015) show that computing teaching helps to improve results in other areas. The sooner coding is introduced as a subject at school, the better students will do in terms of perhaps becoming the designers of new products, not just consumers. 


\section{Conclusions}

The sample computing studies programmes that were prepared under the leadership of the authors are optimal for students and teachers alike. That was seen in the test results and in the fact that as of May 31, 2018, 56 schools (including 48 pilot schools) have changed their general basic education curricula to include computing as a subject. It is also true that the sample programmes led to the approval of a new national general basic education standard that will be mandatory for all schools as of September 1, 2020.

The results of the study show that the extensive and detailed methodological support that was established and tested for each lesson in computing was appropriate for the content of the lessons and ensured that the relevant competences would be achieved. The methodological support included presentations, examples, materials to be passed out, short summaries of theories, exercises and tasks, as well as online environment that helped students to learn the subject while in the classroom and also at other times. In addition to these materials, only teachers have access to lesson plans, methodological instructions and recommendations, and sets of tests. This makes it much easier for teachers to prepare for and teach lessons. This applies to experienced teachers, but particularly to those who are teaching the subject for the first time.

\section{References}

Armoni, M., Gal-Ezer, J. (2014). Early computing education - why? What? When? How? ACM Inroads. 5. p54-59.

Balanskat, A., Engelhardt, K. (2014). Computing our future: Computer programming and coding Priorities, school curricula and initiatives across Europe. European Schoolnet http://www.eun.org/documents/411753/817341/Coding+initiative+r eport+Oct2014/

Balanskat, A., Engelhardt, K. (2015). Computing our future: Computer programming and coding Priorities, school curricula and initiatives across Europe. European Schoolnet http://www.eun.org/documents/411753/817341/Computing+our+futur e_final_2015.pdf

Berry, $\overline{\mathrm{M}}$. (2013). Computing in the national curriculum: A guide for primary teachers. Computing at School. https://www.computingatschool.org.uk/data/uploads/ CASPrimaryComputing.pdf

Department for Education (2013). National curriculum in England: computing programmes of study. https://www.gov.uk/government/publications/nationalcurriculum-in-england-computing-programmes-of-study

Derkevica-Pilskunga, J. (2014). Kā un vai mācīt informātiku jau no 2. klases? (In English: How and whether to teach informatics from $2^{\text {nd }}$ grade?) Skolas Vārds. http:// skolasvards.Iv/sleja/raksti/ka-un-vai-macit-informatiku-jauno-2-klases

European Commission (2016). Coding - the 21st century skill. https://ec.europa.eu/ digital-single-market/coding-21st-century-skill

Eurostat (2015). ICT specialists - statistics on hard-to-fill vacancies in enterprises. Eurostat Statistics Explained. http://web.archive.org/web/20160728021435/http:// ec.europa.eu/eurostat/statistics-explained/index.php/ ICT_specialists_-_statistics_on_hard-tofilī vacancies in_enterprises

Eurostat (2019a). Employed ICT specialists. https: / /appsso.eurostat.ec. europa.eu/ nui/show.do?dataset=isoc_sks_itspt\&lang=en 
Eurostat (2019b). Employed ICT specialists by sex. http://ec.europa.eu/eurostat/ product? code $=$ isoc_sks_itsps \&language $=e n \&$ mode $=$ view

Fernández Cruz, F.J., Fernándež Díaz, M.J., Rodríguez Mantilla, J.M. (2018). El proceso de integración y uso pedagógico de las TiC en los centros educativos madrileños. (In English: The integration process and pedagogical use of iCTs in Madrid schools). Educación XX1, 21(2), 395-416.

Gaile, L. (2014). Skolotāji vienojas par pārmaiņu nepieciešamību informātikas mācīšanā. (In English: Teachers agree on the need for change in teaching informatics.) Ir. https://ir.Iv/2014/08/22/skolotaji-vienojas-par-parmainunepieciesamibu-informatikas-macisanal

Gander, W. et al. (2013). Informatics education: Europe cannot afford to miss the boat. ACM, http://europe.acm.org/iereport/ie.html

Heintz, F., Mannila, L. (2018). Computational thinking for all: an experience report on scaling up teaching computational thinking to all students in a major city in Sweden. Proceedings of the 49th ACM Technical Symposium on Computer Science Education, 137-142. ACM.

Heintz, F., Mannila, L., Färnqvist, T. (2016). A review of models for introducing computational thinking, computer science and computing in K-12 education. 2016 IEEE Frontiers in Education Conference (FIE), Erie, PA, USA, 2016, 1-9.

Heintz, F., Mannila, L., Nordén, L. Å., Parnes, P., Regnell, B. (2017). Introducing programming and digital competence in Swedish K-9 education. Informatics in Schools: Focus on Learning Programming - 10th International Conference on Informatics in Schools: Situation, Evolution, and Perspectives, ISSEP 2017, Proceedings. (Vol. 10696 LNCS, 117-128). (Lecture Notes in Computer Science (including subseries Lecture Notes in Artificial Intelligence and Lecture Notes in Bioinformatics); Vol. 10696 LNCS). Springer Verlag.

IZM (2015). Izglītības un zinātnes ministrija uzsāk digitālo prasmju pilnveides pilotprojektu (In English: Ministry of Education and Science is launching a digital skills development pilot project.) https://www.izm.gov.lv/IV/aktualitates/154-izm-uzsakdigitalo-prasmju-pilnveides-pilotprojektu

IZM (2018). Izglītības un zinātnes ministrija Reorganizētās, slēgtās un dibinātās izglìtības iestādes. (In English: Ministry of Education and Science Reorganised, closed and established educational institutions.) https://www.izm.gov.IV/IV/publikacijas-unstatistika/reorganizetas-slegtas-un-dibinatas-izglitibas-iestades

IZM (2019). Izglītības un zinātnes ministrija Oficiālā statistika par vispārējo izglīî̄bu (In English: Ministry of Education and Science Official statistics on general education.) https://www.izm.gov.lv/lv/publikacijas-un-statistika/

statistika-par-izglitibu/statistika-par-visparejoizglitibu/2018-2019-m-g3

Joint Task Force on Computing Curricula, Association for Computing Machinery (ACM) and IEEE Computer Society (2013). Computer Science Curricula 2013: Curriculum Guidelines for Undergraduate Degree Programs in Computer Science. ACM, New York, NY, USA.

Jones, S. P. (2011). Computing at School International comparisons. https:// www. computingatschool.org.uk/data/uploads/internationalcompari sons-v5.pdf

Jones, S. P., Mitchell, B., Humphreys, S. (2013). Computing at school in the UK. http://research.microsoft.com/en-us/um/people/simonpj/ papers/Cas/ComputingAtSChoolCACM.pdf

Kalelioğlu, F. (2015). A new way of teaching programming skills to K-12 students: Code.org. Computers in Human Behavior, 52, 200-210.

Kuzmina, I. (2015). Informātiku nomain̄̄s datorika. (In English: Informatics will be replaced by computing.) LA.LV. http://www. Ia.IV/informatiku-nomainis-datorika 
MK (2014). Ministu Kabinets Noteikumi par valsts pamatizglitīibas standartu, pamatizglìtības mācību priekšmetu standartiem un pamatizglītîbas programmu paraugiem. (In English: Cabinet of Ministers. Regulations Regarding the State Standard in Basic Education, the Subjects of Study Standards in Basic Education and Model Basic Educational Programmes.) Latvijas Vēstnesis, 165 (5225)

PKC (2012). Pārresoru koordinācijas centrs Nacionālais attīstības plāns 2014.-2020.gadam. (In English: Cross-Sectoral Coordination Centre. National Development Plan of Latvia for 20142020.) http://polsis.mk.gov.lv/api/file/file50126.pdf

Vezis, V. et al. (2006). INFORMĀTIKA Pamatizglīīibas mācību priekšmeta programmas paraugs. (In English: A sample informatics study programme for general basic education.) Izglìtíbas satura un eksaminācijas centrs. https://visc.gov.lv/vispizglitiba/saturs/ dokumenti/programmas/pamskolai/informatika.pdf

Vezis, V. et al. (2015a). DATORIKA 1.-9.klasei Mācību priekšmeta programmas paraugs (izglīîibas iestādēm, kas realizē pamatizglīîibas matemātikas, dabaszinību un tehnikas virziena programmu) (In English: A sample computing study programme for the $1^{\text {st }}$ to the $9^{\text {th }}$ grade at schools which teach maths, natural sciences and technical subjects) Valsts izglìtības satura centrs. https://visc.gov.IV/vispizglitiba/saturs/dokumenti/ programmas/pamskolai/datorika_1_9.pdf

Vezis, V. et al. (2015b). DATORIKA 1.-3.klasei Mācību programmas paraugs integrētai datorikas jautājumu apguvei (In English: A sample computing study programme with a series of questions for the integrated teaching of these subjects from the $1^{\text {st }}$ to the $3^{\text {rd }}$ grade) Valsts izglitības satura centrs. https://visc.gov.lv/vispizglitiba/saturs/ dokumenti/programmas/pamskolai/datorika_1_3.pdf

Vezis, V. et al. (2015c). DATORIKA 4.-6.klase Mācību programmas paraugs (In English: A sample computing study programme for the $4^{\text {th }}$ to the $6^{\text {th }}$ grade) Valsts izglititibas satura centrs. https://visc.gov.1v/vispizglitiba/saturs/dokumenti/programmas/ pamskolai/datorika_4 6.pdf

Vezis, V. et al. (2015d). DATORIKA 7.-9.klasei Mācību programmas paraugs (In English: A sample computing study programme for the $7^{\text {th }}$ to the $9^{\text {th }}$ grade) Valsts izglititibas satura centrs. https://visc.gov.lv/vispizglitiba/saturs/dokumenti/programmas/ pamskolai/datorika 79 parejasposmam.pdf

Vezis, V. et al. (2015e). DATŌRIKĀ 7.-9.klase padziḷināti Mācību programmas paraugs (In English: A sample computing study programme for more in-depth studies of the topics from the $7^{\text {th }}$ to the $9^{\text {th }}$ grade) Valsts izglititibas satura centrs. https://visc.gov. IV/ vispizglitiba/saturs/dokumenti/programmas/pamskolai/datorika_7 9 padz.pdf

Vezis, V., Krumins, O. (2018). Fifty-Five Years of the Teaching of Informatics at Latvian Schools. Baltic Journal of Modern Computing, 6(2), 107-118.

Wing, J. M. (2006). Computational thinking. Communications of the ACM, 49(3), 33-35.

VISC (2015a). Valsts izglīīibas satura centrs Programmas un eksperti. (In English: National Centre for Education Programmes and experts.) https://visc.gov.Iv/vispizglitiba/ saturs/dokumenti/2015/20150206_programmas_un_eksperti.pdf

VISC (2015b). Valsts izglìtības satura centrs Aprō̄ācijā iesaistīto pilotskolu saraksts. (In English: National Centre for Education List of pilot schools involved in testing.) https://visc.gov.IV/vispizglitiba/saturs/dokumenti/2015/ 20150206_aprobac_iesaistitas_skolas.pdf

Received August 21, 2019, accepted September 7, 2019 